\title{
A Monocot Flower, Mirafloris burmitis gen. et sp. nov. (Monocots: Angiospermae), in Burmese Amber
}

\author{
George Poinar, Jr. ${ }^{a}$ \\ ${ }^{a}$ Department of Integrative Biology, Oregon State University, Corvallis, Oregon 97331. Email: \\ poinarg@science.oregonstate.edu
}

(C) The Author, 2021

\begin{abstract}
A six-merous, slightly bisymmetric monocot flower in mid-Cretaceous Burmese amber is described as Mirafloris burmitis gen. et sp. nov. The perianth is composed of two whorls of $3+3$ distinctly vascularized tepals connected by an irregular network of veinlets. There are two whorls of $3+3$ free stamens with latrorse dehiscence positioned opposite the tepals. A single 3-lobed style arises from the center of the flower. Perigonal nectaries are located at the base of the inner tepals. The oval-spherical pollen possess a single, longitudinal suture. The fossil shows affinities to the order Liliales and family Liliaceae. This is the first showy monocot flower described from Burmese amber and based on recent phylogenetic studies, may be one of the earliest records of a fossil member of the Liliales.
\end{abstract}

\author{
Revised: 28-07-2021 \\ KEYWORDS \\ mid-Cretaceous \\ Flower \\ Monocot \\ Liliales \\ Myanmar
}

ARTICLE HISTORY

Received: 4-06-2021

Accepted: 19-08-2021

\section{Introduction}

Resin, with its miraculous preserving qualities of ancient organisms that have fossilized into amber, is one of the wonders of the natural world. While the exact process of preservation is unknown, certain products in the resin become active immediately after organisms have became entombed, long before the resin hardens. These chemicals act as natural embalming agents that fix and dehydrate the organism's tissues. A long period of polymerization ensues, during which volatile terpenes in the resins escape and nonvolatile terpenes bind together to form compounds resistant to natural decay (Poinar \& Hess, 1985).

Burmese amber in Myanmar has provided a unique view of plants and animals from the midCretaceous (Cruickshank \& Ko, 2003; Ross, 2020). While much attention has been given to animal life in these amber deposits, a variety of other organisms, including liverworts, mosses, fungi, and angiosperms, are also present. Dicotyledonous flowers have been previously described from these deposits (Liu et al. 2018; Poinar, 2017; Poinar \& Chambers, 2005, 2018, 2019, 2020; Chambers \& Poinar, 2010, 2020; Chambers et al., 2010).

Described in the present paper is the first showy monocot flower in Burmese amber. This flower is characterized by hexamerous perianth arranged in two whorls; $3+3$ stamens positioned opposite the tepals, a single 3-lobed style, perigonal nectaries positioned at the base of the inner tepals and oval-spherical pollen with a single, longitudinal aperture. Possessing these features aligns the fossil with members of the monocot family Liliaceae, one of the largest families of flowering plants. This new species, with its interesting features, provides us with a view of floral diversity that existed in the mid-Cretaceous Burmese amber forest.

\section{Materials and Methods}

The specimen originated from the Noije Bum 2001 Summit Site mine first excavated in the Hukawng Valley in 2001 and located southwest 
of Maingkhwan in Kachin State (26 $20^{\prime} \mathrm{N}$, $96^{\circ} 36^{\prime} \mathrm{E}$ ) in Myanmar. Based on paleontological evidence this site was dated to the late Albian of the Early Cretaceous (Cruickshank and Ko, 2003), placing the age at 97 to $110 \mathrm{Ma}$. A zircon $\mathrm{U}-\mathrm{Pb}$ and trace element analyses of amber from different locations in northern Myanmar confirmed an age of around $100 \mathrm{Ma}$ for amber from the Hukawng Valley as well as an age range of 72-110 Ma for amber from other sites in northern Myanmar (Xing and Qui, 2020). Nuclear magnetic resonance (NMR) spectra and the presence of araucaroid wood fibers in amber samples from the Noije Bum 2001 Summit Site indicate an araucarian tree source of the amber (Poinar et al., 2007).

Observations and photographs were made with a Nikon SMZ-10 R stereoscopic microscope and Nikon Optiphot compound microscope with magnifications up to $800 \mathrm{X}$. Helicon Focus Pro X64 was used to stack photos for better depth of field.

The specimen is post-anthesis but some dislodged anthers still retain pollen grains. Damage from herbivores is evident and two rove beetles (Coleoptera: Staphylinidae) are associated with two of the remaining anthers.

Results

Clade: Angiosperms

Clade: Monocots

Order: Liliales Perleb, (1826)

Family: Liliaceae Juss.

Mirafloris gen. nov.

Type species: Mirafloris burmitis sp. nov.

Diagnosis: Six-merous slightly bisymmetric flower with six simple ovate tepals arranged in 2 whorls; central median tepal of inner whorl slightly larger than 5 remaining subequal tepals; 6 stamens $(3+3)$, shorter than perianth, with latrose dehiscence, positioned opposite tepals, filaments short; anthers basifixed, broadly oblong, narrowing toward apex, dehiscence longitudinal; style trifid, in center of flower; perigonal nectaries located at base of inner tepals; pollen with single, longitudinal aperture.

Etymology: Genus from the Latin "miror" = strange and the Latin "floris" = flower, in regards to its unique features.
Mirafloris burmitis gen. et sp. nov.

Description (Figs.1-6): Flower bisexual, hexamerous, bisymmetric (2 planes of symmetry can be placed through it (Dahlgren et al.,1985)), with short pedicel and flat receptacle; tepals $3+3$ (dicyclic), broadly ovate, separate, clawed, with 3-5 major basal veins; tepals in outer whorl similar in size; tepals in inner whorl with large median tepal with recurved tip; median tepal larger than two smaller tepals of inner whorl that are similar in size to tepals of outer whorl; epidermal surfaces of all tepals with long unicellular trichomes, some of which have glandular bases; deeply sunken lunate perigonal nectaries located at base of inner tepals; stamens $3+3$ (diplostemonous), free, included (much shorter than perianth); filaments short, glabrous, slightly dilated basically; anthers basifixed, broadly oblong, narrowing toward apex; dehiscence longitudinal; pollen oval-spherical, with single sulcus (monoaperturate); style simple, narrow, trifurcate near center; stigmas trilobate, with apex of each lobe rounded.

Measurements: Greatest flower diameter, 5.5 $\mathrm{mm}$; length large inner median tepal, $3.2 \mathrm{~mm}$; width large inner median tepal, $2.1 \mathrm{~mm}$; length other 2 inner and 3 outer tepals, $2.0-2.2 \mathrm{~mm}$; length perigonal nectaries at base of inner tepals, $700 \mu \mathrm{m}$; length filaments $100-140 \mu \mathrm{m}$, length anthers 500-800 $\mu \mathrm{m}$; length style, $916 \mu \mathrm{m}$, fused basal portion of style, $415 \mu \mathrm{m}$; greatest dimension pollen grains, $35-42 \mu \mathrm{m}$.

Remarks: The upper margin of the median inner tepal is recurved (Fig. 3A). In the basic reconstruction of the flower (Fig.6), this tepal is depicted with the recurved portion outstretched as it is likely to have been in life. Four stamens are still attached and two of these have been damaged by herbivores (Fig. 5). The pollen grains, showing sulci and nuclei were exposed in one of the damaged, dislodged stamens (Fig. 4B).

Etymology: Specific epithet indicates the origin of the flower.

Holotype: Deposited in the Poinar amber collection (B-An-22) maintained at Oregon State University.

Type locality: Myanmar (Burma): Kachin Province: Noije Bum 2001 Summit Site amber mine. 
Stratigraphic horizon: Hukawng Valley SW of

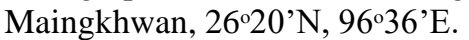

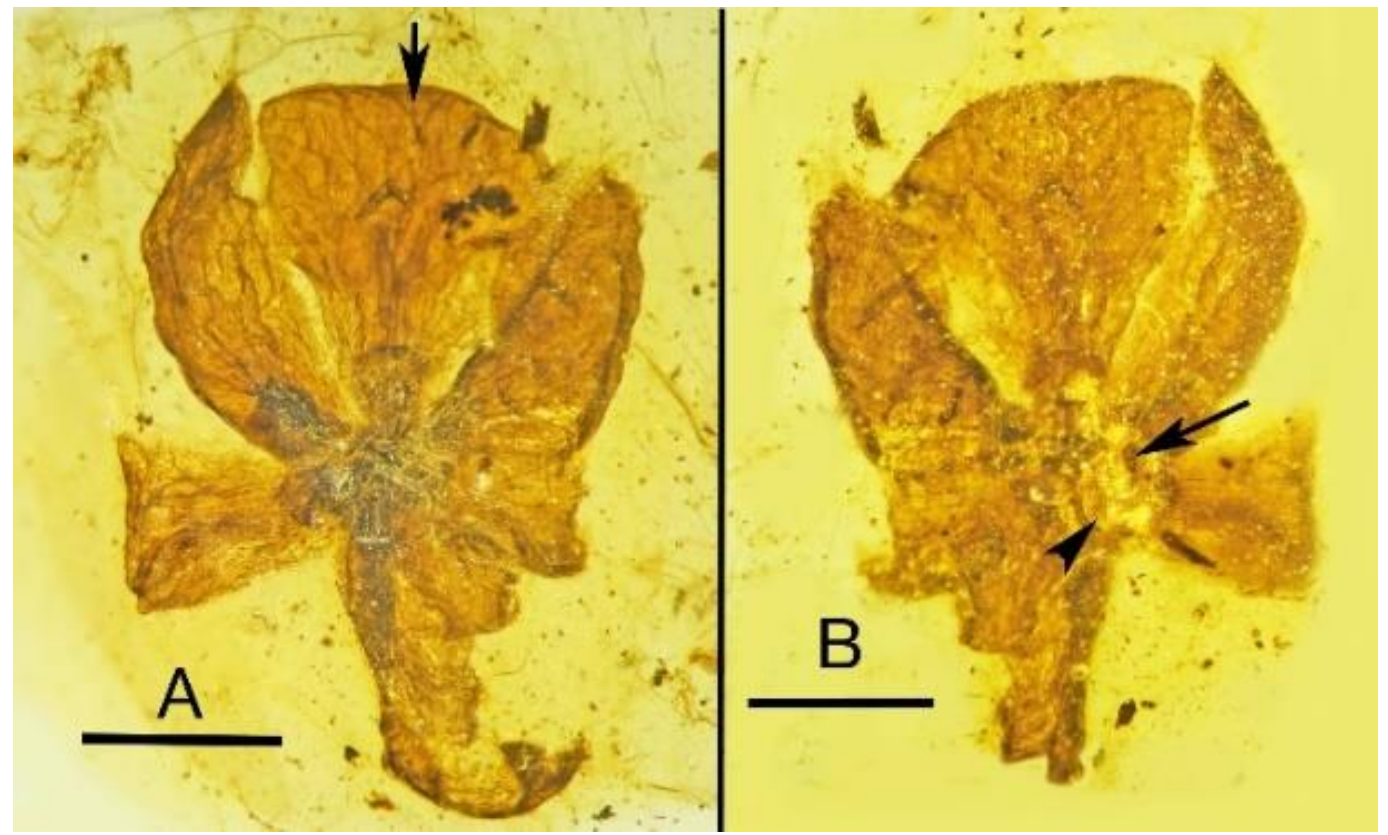

Figure 1. Holotype of Mirafloris burmitis in Burmese amber. A. Apical view of flower. Arrow shows enlarged median, inner tepal. Bar $=1.5 \mathrm{~mm}$. B. Basal view of flower. Arrow shows pedicel. Arrowhead shows receptacle. Bar $=1.4 \mathrm{~mm}$.

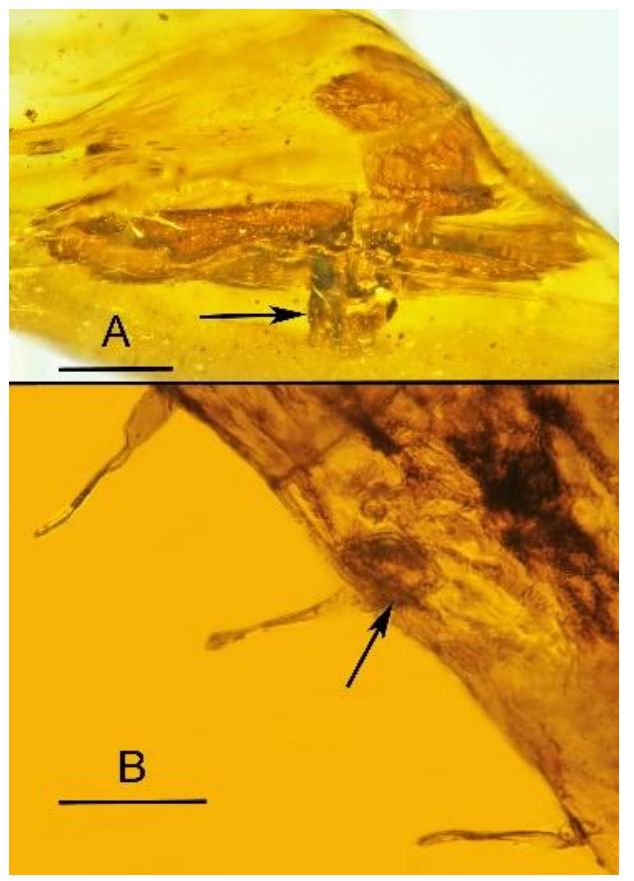

Figure 2. Holotype of Mirafloris burmitis in Burmese amber. A. Lateral view showing pedicel and basal portion of receptacle (arrow). Bar $=0.9$ $\mathrm{mm}$. B. Epidermal trichomes on inner tepal. Note epidermal gland at base of middle trichome (arrow). Bar $=88 \mu \mathrm{m}$.

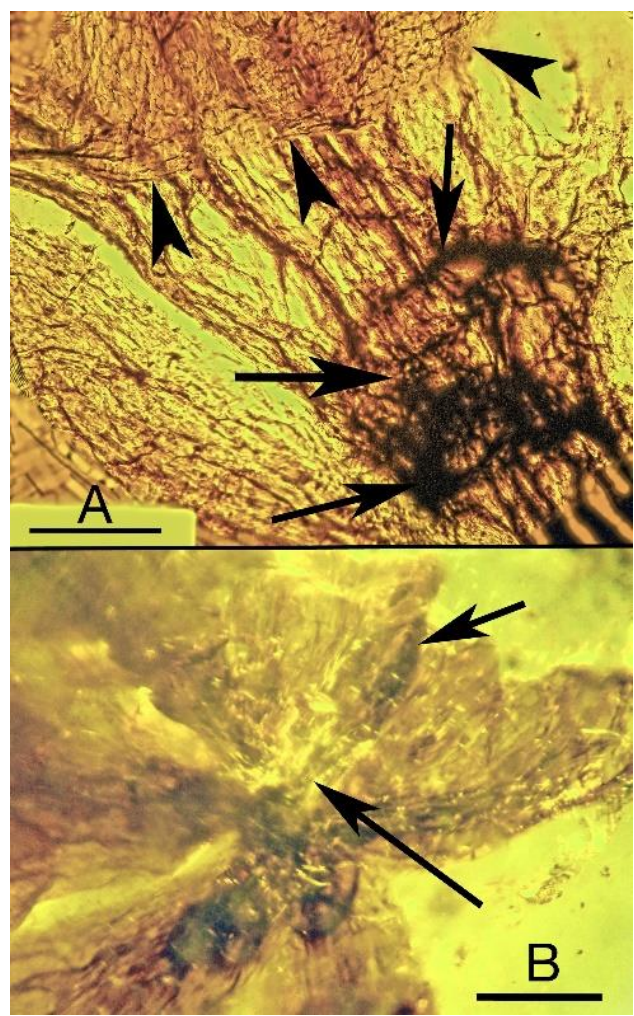

Figure 3. Holotype of Mirafloris burmitis in Burmese amber. A. Base of median inner tepal showing pattern of venation and recurved margin 
(arrowheads). Note 5 major veins at base of tepal. Upper arrow shows crescent above nectary gland. Lower 2 arrows show extent of perigonal nectary gland. Bar $=400 \mu \mathrm{m}$. B. Stamen with filament (lower arrow) and anther (upper arrow). Bar $=540$ $\mu \mathrm{m}$.

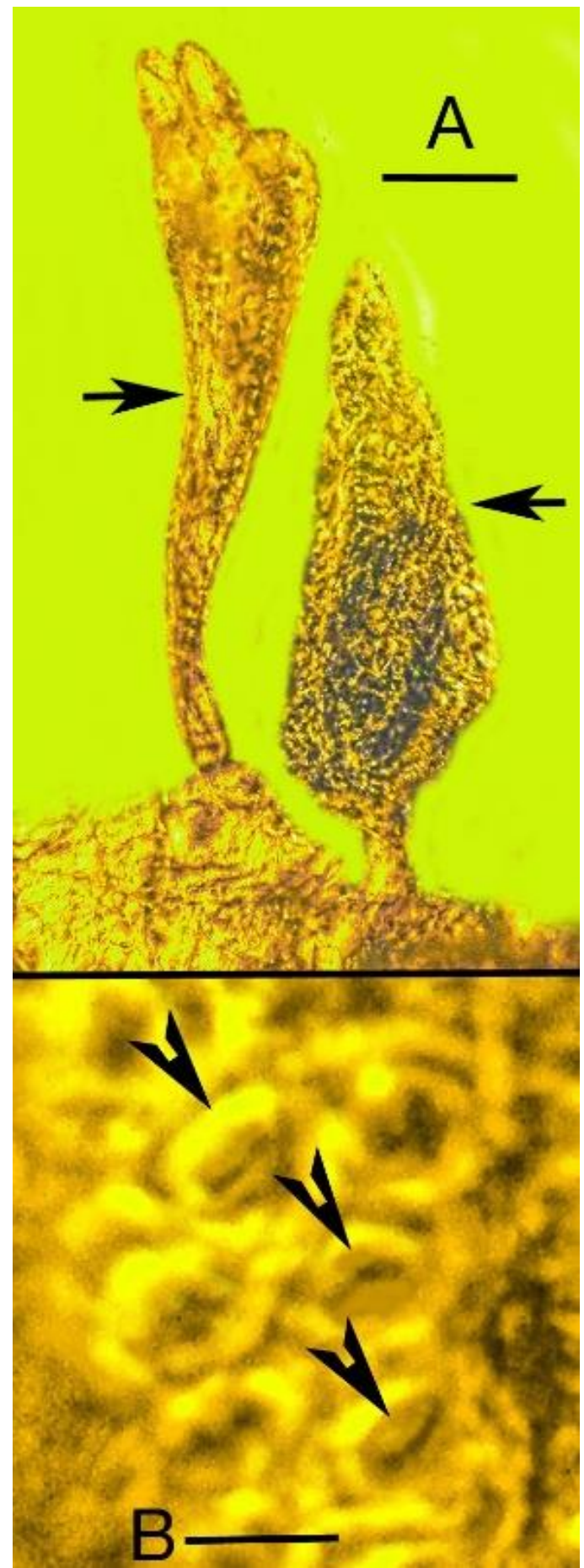

Figure 4. Holotype of Mirafloris burmitis in Burmese amber. A. Style (left arrow) and adjacent anther (right arrow). Left arrow shows where style divides into 3 stigmatic lobes. Bar $=172 \mu \mathrm{m}$. B. Pollen grains in exposed anther. Arrowheads show sulci (equatorial views). Other grains show nuclei in various positions. Bar $=31 \mu \mathrm{m}$.

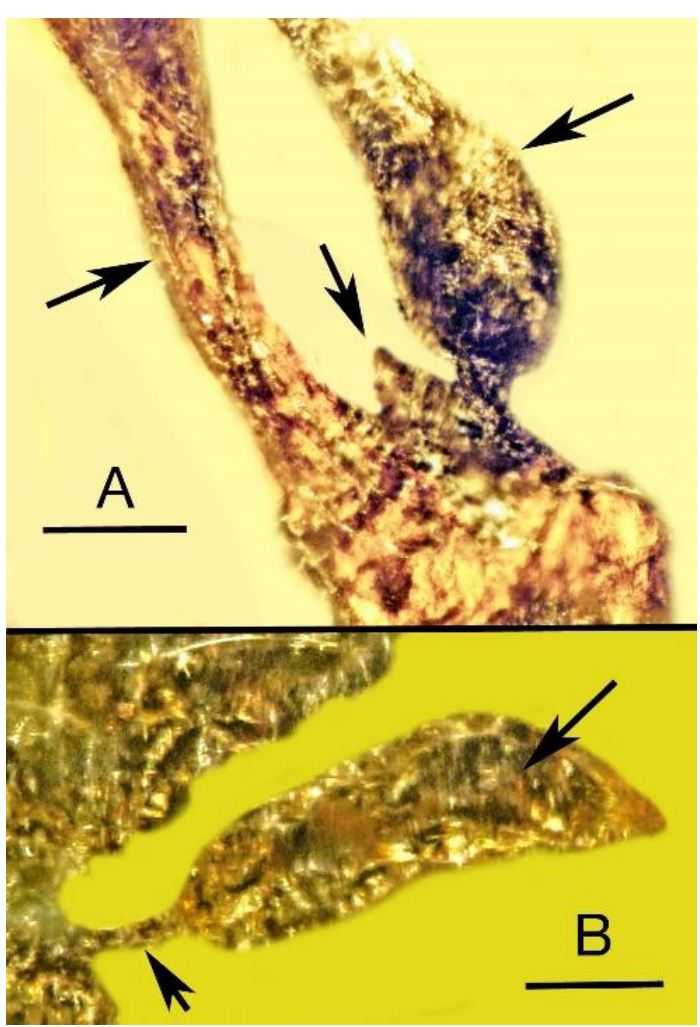

Figure 5. Holotype of Mirafloris burmitis in Burmese amber. A. Base of style (left arrow) and lower portion of second stamen (right arrow). Middle arrow shows rove beetle at base of filament. Bar $=200 \mu \mathrm{m}$. B. Stamen showing basifixed filament (left arrow) and anther. Right arrow shows a rove beetle inside the anther. Bar = $190 \mu \mathrm{m}$. 


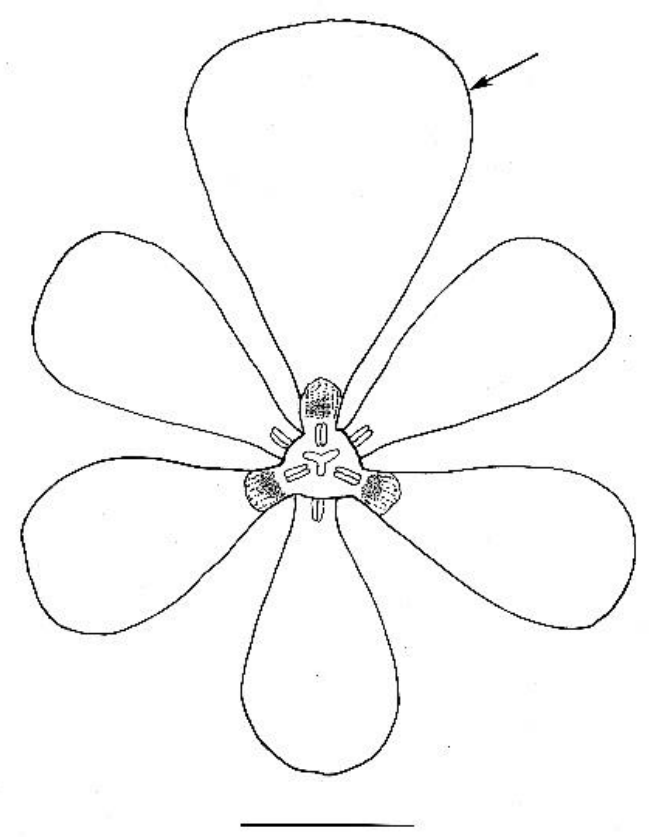

Figure 6. Reconstructed apical view of Mirafloris burmitis holotype in Burmese amber. Note larger median tepal (arrow). $\mathrm{Bar}=1.3 \mathrm{~mm}$.

\section{Discussion}

Mirafloris burmitis can be considered weakly bisymmetric or zygomorphic (Dahlgren et al., 1985). Based on its hexamerous condition with $3+3$ tepals, perigonal nectaries, $3+3$ stamens, trifurcate style and monoaperturate pollen, Mirafloris burmitis is considered to represent a monocot with affinities to the family Liliaceae (Edlund et al., 2004; Remizowa et al., 2010; Meyers et al., 2015).

Based on phylogenetic studies, the crown age of the Liliaceae is (c.) 85 Mya in the Late Cretaceous (Kim and Kim, 2018). This date corresponds with the (c.) 90 Mya age for the Liliaceae using the Angiosperm phylogeny Group II (APG II) classification (Bremer and Janssen, 2006) and the (c.) 100 mya age of Burmese amber from this site (Xing and Qui, 2020). Bremer and Janssen, (2006) concluded that the Liliaceae originated in South Gondwana, which is congruent with the recent findings indicating that fossils in Burmese amber have a Gondwanan origin and later rafted to their present position in Myanmar (Poinar, 2018). This would make Mirafloris one of the earliest known flowers with affinities to the Liliaceae.
Perigonal nectaries at the base of the inner tepals are especially common in representatives of the Liliaceae (Dahlgren, 1985; Kubitzki and Huber, 1998; Smets et al., 2000; Remizowa et al., 2010). The fossil has additional features that occur in extant members of the Liliaceae. These include the shape of the tepals with deeply sunk perigonal nectaries that are similar to those of Calochortus greeni S. Watson (Meyers et al., 2015). Also the size and position of the stamens with anthers surrounding the style are similar to the condition in Scoliopus hallii S. Watson (Meyers et al., 2015) and the free stamens, flat receptacle and threelobed style are similar to those of Toxicoscordion venenosum (S. Watson) Rydberg (Meyers et al., 2015).

In dorsal view (Fig. 1A), it is clear that the two lower right tepals with partly torn edges were damaged by herbivores, thus making them appear to be fused, but they are actually separate. Being post-anthesis, the anthers are somewhat desiccated and difficult to depict against the dark floral center. Two anthers are associated with small rove beetles (Staphylinidae: Coleoptera), one of which is inside the anther (Fig. 5B). Rove beetles are known to feed and serve as pollinators of various angiosperms today (Bernhardt, 2000). It was fortunate that a herbivore fed on an adjacent stamen, thus exposing clusters of pollen grains (Fig. 4).

While a member of the Poales was previously described from Burmese amber (Poinar, 2004), Mirafloris burmitis is the first showy monocot flower described from this amber site. Based on recent phylogenetic studies, Mirafloris may be one of the earliest fossil records of a member of the Liliales. This early monocot lineage, with its interesting assortment of characters, provides us with a fleeting glimpse of additional floral diversity in the mid-Cretaceous Burmese amber forest.

\section{Disclosure statement}

No potential conflict of interest was reported by the author.

\section{Acknowledgements}

The author thanks Kenton Chambers and Peter Bernhardt for discussions on the morphological features of the flower. 


\section{References}

Bernhardt, P. (2000). Convergent evolution and adaptive radiation of beetle-pollinated angiosperms. Plant Systematics and Evolution, 222, 293-320. https://doi.org/10.1007/978-3-70916306-1_16

Bremer, K. \& Janssen, T. (2006). Gondwanan origin of major monocot groups inferred from dispersal-vicariance analysis. Aliso: a journal of systematic and evolutionary Botany, 22, 22-27. https://doi.org/10.5642/aliso.20062201. $\underline{03}$

Chambers, K.L. \& Poinar, Jr, G.O. (2020). Thymolepis toxandra gen. et sp. nov., a mid-Cretaceous fossil flower with horseshoe-shaped anthers. Journal of the Botanical Research Institute of Texas, 14 , 57-64. https://doi.org/10.17348/jbrit.v14.i1.896

Chambers, K.L., Poinar, Jr, G.O., \& Buckley, R. (2010). Tropidogyne, a new genus of Early Cretaceous Eudicots (Angiospermae) from Burmese amber. Novon, 20(1), 23-29.

Cruickshank, D., \& Ko, K., (2003). Geology of an amber locality in the Hukawng Valley, northern Myanmar. Journal of Asian Earth Sciences, 21, 441-455. https://doi.org/10.1016/S13679120(02)00044-5

Dahlgren, R.M.T., Clifford, H.T., \& Yeo, P. F. (1985). The Families of the Monocotyledons. Springer Verlag, Berlin.

Edlund, A. F., Swanson, R. and Preuss, D. (2004). Pollen and stigma structure and function: the role of diversity in pollination. The Plant Cell, 16, S84-S97. https://doi.org/10.1105/tpc. 015800

Kim, J.S. \& Kim, J-H. 2018. Updated molecular phylogenetic analysis, dating and biogeogrphical history of the lily family (Liliaceae: Liliales). Botanical Journal of Linnean Society, 187(4), 579-593. https://doi.org/10.1093/botlinnean/boy0 $\underline{31}$

Kubitzki, K. and Huber, H. (eds.) (1998). The families and genera of vascular plants (vol.3). Flowering plants. Monocotyledons: Lilianae (except Orchidaceae). Berlin, Springer-Verlag. https://doi.org/10.1007/978-3-662$\underline{07255-4}$
Liu, Z-J., Huang, D., Cai, C., \& Wang, X. (2018). The core eudicot boom registered in Myanmar amber. Scientific Reports, $8(1), 16765$.

https://doi.org/10.1038/s41598-018$\underline{35100-4}$

Meyers, S. C., Jaster,T., Mitchell, K. E. and Hardison, L.K. (eds.) (2015). Flora of Oregon (vol.1): Pteridophytes, Gymnosperms, and Monocots. Bot. Res. Instit. Texas, Fort Worth.

Poinar Jr., G.O. (2004). Programinis burmitis gen. et sp. nov., and P. laminatus sp. nov., Early Cretaceous grass-like monocots in Burmese amber. Australian Systematic Botany, 17(5), 497-504. https://doi.org/10.1071/SB04002

Poinar Jr., G.O. (2017). A mid-Cretaceous Lauraceae flower, Cascolaurus burmitis gen. et sp. nov., in Myanmar amber. Cretaceous Research, 71, 96-101. https://doi.org/10.1016/j.cretres.2016.11 .015

Poinar Jr., G. (2018). Burmese amber: evidence of Gondwanan origin and Cretaceous dispersion. Historical Biology, 31, 13041309.

https://doi.org/10.1080/08912963.2018. $\underline{1446531}$

Poinar Jr., G.O., \& Chambers, K.L. (2005). Palaeoanthella huangii gen. et sp. nov., an Early Cretaceous flower (Angiospermae) in Burmese amber. Sida, 21(4), 2087-2092.

Poinar Jr., G.O. \& Chambers, K.L. (2018). Setitheca lativalva gen. et sp. nov., a fossil flower of Laurales from midCretaceous Myanmar amber. Journal of the Botanical Research Institute of Texas, 12(2), 643-653.

Poinar Jr., G.O., \& Chambers, K.L. (2018). Fossil flowers of Lachnociona camptostylus sp. nov., a second record for the genus in mid-Cretaceous Myanmar amber. Journal of the Botanical Research Institute of Texas, 12(2), 655-666.

Poinar Jr., G.O., \& Chambers, K.L. (2019). Dispariflora robertae gen. et sp. nov., a mid-Cretaceous flower of possible Lauralean affinity from Myanmar amber. Journal of the Botanical Research Institute of Texas, 13(1), 173183.

Poinar Jr., G.O., \& Chambers, K.L. (2020). Cyathitepala papillosa gen. et sp. nov., a mid-Cretaceous fossil flower from 
Myanmar amber with valvate anthers. Journal of the Botanical Research Institute of Texas,14, 351- 358. https://doi.org/10.17348/jbrit.v14.i2.101 $\underline{3}$

Poinar Jr., G.O., \& Hess, R. (1985). Preservative qualities of recent and fossil resins: Electron micrograph studies on tissue preserved in Baltic amber. Journal of Baltic Studies, 16(3), 222-230. https://doi.org/10.1080/0162977850000 $\underline{0141}$

Poinar, Jr., G.O., Lambert, G.J.B., \& Wu, Y. (2007). Araucarian source of fossiliferous Burmese amber: spectroscopic and anatomical evidence Journal of the Botanical Research Institute of Texas, 1(1), 449-455.

Remizowa, M.V., Sokoloff, D.D., \& Rudall, P.J. (2010). Evolutionary history of the monocot flower. Ann. Missouri Bot. Garden, 97, 617-645.
Ross, A.J. (2020). Supplement to the Burmese (Myanmar) amber checklist and bibliography, 2019. Palaeoentomology, 3,103-118. https://doi.org/10.11646/palaeoentomol ogy.3.1.14

Smets, E.F., Ronse Decraene, L.P., Caris, P., \& Rudall, P.J. (2000). Floral nectaries in Monocotyledons: Distribution and Evolution. In Wilson, K.L. \& Morrison, D.A. (eds.), Monocots: Systematics and Evolution (pp.230-240). CSIRO, Melbourne.

Xing, L., \& Qui, L. (2020). Zircon U-Pb age constraints on the mid-Cretaceous Hkamit amber biota in northern Myanmar. Palaeogeography, Palaeoclimatology, Palaeoecology, 558,109960. https://doi.org/10.1016/j.palaeo.2020.10 $\underline{9960}$

Publisher's note: Eurasia Academic Publishing Group (EAPG) remains neutral with regard to jurisdictional claims in published maps and institutional affiliations.

Open Access This article is licensed under a Creative Commons Attribution-NoDerivatives 4.0 International (CC BY-ND 4.0) licence, which permits copy and redistribute the material in any medium or format for any purpose, even commercially. The licensor cannot revoke these freedoms as long as you follow the licence terms. Under the following terms you must give appropriate credit, provide a link to the license, and indicate if changes were made. You may do so in any reasonable manner, but not in any way that suggests the licensor endorsed you or your use. If you remix, transform, or build upon the material, you may not distribute the modified material.

To view a copy of this license, visit https://creativecommons.org/licenses/by-nd/4.0/. 